\title{
ナトリゥムアミド溶融法による有機物 および無機物中の炭素の検出
}

\author{
百 瀬 勉, 上田陽，向井 良子**
}

\begin{abstract}
ナトリウムアミドはほとんどすべての種類の有機化合物抢よび無機化合物中の炭素と反心してシアン 化ナトリウム究生ずる.したがってシアンイオンをベルリン青として検出し, 微量の炭素の検出が可能 である。

この検出法苍確実に抢てなうためには検体にナトリウムアミドのほかに塩化ナトリウムと带鉛末を添 加して加熱する必要がある。乙れら添加物によりシアン化ナトリウムが加熱により分解し，また炭素が 炭酸ガスとして逃出することが防げる。この方法による確認限度は炭素として 35〜75 rであった。

この検出法における障害物を検討した結果，イオウを含む化合物は 50 倍まで，他の多くの化合物は 数百倍まで共存しても障害しなかつた。
\end{abstract}

有機物または無機物中の炭素の検出には，これを燃焼 してタールの生成により，または炭酸ガスにより確認す る方法が試みられたが，前者はタールの生成なしに然焼 する有機物の場合には適応できず, 後者は空気中の炭酸 ガスを完全に除去しておこなう必要がある。したがって これ程鋭敏でないが，有機物を三酸化モリブデンととも に灰化して生ずるモリブデン青による方法1)，ヒ酸銀と 加熱して生ずる銀による方法 ${ }^{2)}$ ，およびヨウ素酸カリウ ムと加熱して生ずるヨウ化カリウムが過剩のヨウ素酸力 リウムと作用して生ずるヨウ素により確認するす法3な どが用いられる：これら活いずれも炭素の還元力を利用 したものであるから酸化されやすい物質はこ机らの反忘 を障菑古る。このほか炭素をマグネシウム末と加熱して カーバイドとし，こ在水で分解して生ずるアセチレン 誘導体を $\mathrm{Cu}(\mathrm{I})$ で呈色させる方法4もあるが，これはガ ラスふらのケイ素化合物を，さらに S, P, Asなどを含 有特る場合には，生成したそ机らの水素化物を除去しな ければならない。

著者らは J. B. Nieder1, J. A. Sozzi の報じてい る5)硫酸アンモニウム其存のもとに出こなうナトリウ ム溶融法学追試して一般性がないこと它認め，これに代 りナトリウムアミドを使用したカがよいことに父付き， 系統的に笑験を試みたところ好結果を得た。ナトリウム アミドは融点約 $210^{\circ} \mathrm{C}$ で反応性に富み，かつナトリウ

* 有機分析(第 21 報)，本報は Chem. Pharm. Bull., 6，322（1958）に速報した。第 20 報：Talanta，in press (1959).

** 九州大学医学部薬学科 : 福岡市堅粕
ムほどの仜険性もなくまた流酸アンモニウム先よ゙の窒素 化合物を加える必要がない。

本反応は硬質々ク口試験管中で炭米化食物芯ナトリウ ムアミドと加熱溶融し，冷後水壳加えてロ過し，口液に ついてシアンイオンの確䛱をベルリン青によっておこな うのである。微量シアンイオン0检山泣汇は $\mathrm{Cu}$-ベンジ ジン法またはジフェニルカルバジド-Hg 泣6)があるが， こ秃らは鋎敏に過ぎて，ナトリウムアミド巾に微量含ま れる炭酸填が陽性に出る危险があり，本友伈にはベルリ ン青が適当である。

\section{1 実験 D部}

\section{$1 \cdot 1$ 試 薬}

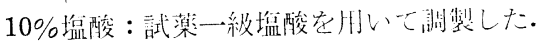

$2 \%$ 第一鉄試液 : 試染特級硫酸第一鉄アンモニウム 200 $\mathrm{mg}$ 㱏蒸留水 $10 \mathrm{cc}$ に溶加した。

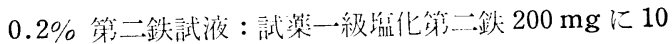

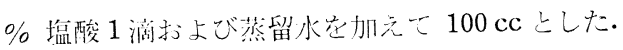

\section{$1 \cdot 2$ 炭素の検出}

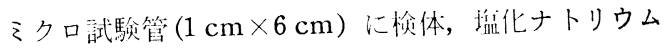
約 $20 \mathrm{mg}$, 西鉛末*** 約 $40 \mathrm{mg}$ を入れてよく混和し, ナトリウムアミドの絬晶の透明な部分****丧とり，こま

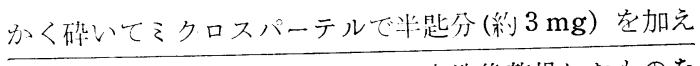

***亜鉛末は希塩酸で処理し, 水洗後乾燥したものを 用いた。

****白い部分は炭酸塩になっている打それがあり本反 応を陽性にすることがある。 
てよく混和し, 初め徐々に次第に強く加熱し赤熱するに 到らしめる. 冷後蒸留水 5 滴を加えてかきまぜてロ過し 沈殿䓘蒸留水 3 滴で洗浄する. 口液に第一鉄試液 1 滴を 加えて温め, 冷後 $10 \%$ 掹酸 2 滴を加えて酸性とし，第 二鉄試液 1 滴を加える. 濃青色军呈すれば陽性である. 同時に検体を加えずに空試験を行なう．本法で各試料の 嫶化ナトリウム倍散を用いて確涩限度を調べた結果は Table I のと抢りである.

Table I Limit of detection of carbon in

\begin{tabular}{ll|ll}
\hline Resorcinol & $50 r$ & Carbon & $75 r$ \\
Acetanilide & 35.5 & Anthraquinone & 40 \\
Glucose & 40 & Potassium bicarbonate & 40 \\
\hline
\end{tabular}

\section{2 結果と考察}

本法法武料に塩化ナトリウムと西鉛末を添加してナト リウムアミドと加熱したが，炭菜化合物とナトリウムア ミドのみを加熱しても抗こなことができる。しかしこ の埸合には加熱温度が問題となる。亦なわち，(a)でき たシアン化ナトリウムが加熱によって分解する抢それの 岕ることと，(b)炭素がナトリウムアミドと反応する前 に炭酸ガスとなって逃げる打それがある。（a）はシアン イオン $100 \gamma$ に相当するシアン化ナトリウムを直接加熱 したもの，塯化ナトリウム总加えて加熱したもの，抢よ

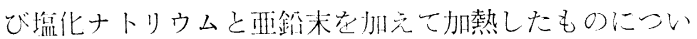
てベルリン布反応茬試みたとこ7，塩化ナトリウム 20 mg 以上，または睢化ナトリウムと亜鉛末を加えたもの ではあまり影響なく，直接加熱したものはほとえぞ陰性

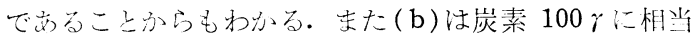

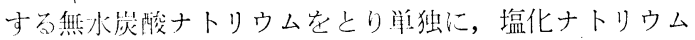

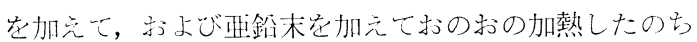

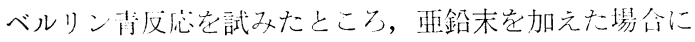
明らかに隰性であり他は不明確であったことからもわふ る.したがって反坴条件として, 篮化ナトリウム $20 \mathrm{mg}$, 西鎑末 $40 \mathrm{mg}$ 岩共存させておこなうことにした。なお 炭素が比較的多量存在与る時はこれらの心配は少なく， 加熱し、可ぎないように注意す机ば炭酸塩を少量含さナト リウムアミドを用いても滥化ナトリウムを加えて，ある いは直接に検出它抢こなうことができる。

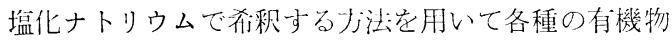
について検討した絬果は Table II のとおりでほとえど すべての種類の有機化仝物中の炭素がこの方法で検出さ れる。

木反応の其存物質による影響をレゾルシン $300 \gamma$ （炭
素として $200 \gamma$ ）を用いて試みた結果は Table III に 示すと抢りで，アルカリ金属塩の場合たとえば䘏化ナト リウムでは炭素の 5000 倍共存しても影響なく, 還元性 金属たとえば亜鉛末では 5000 倍共存しても何ら影響は 認められない，金属酸化物の場合は 100 倍までは影響な いが，それ以上では障害する。また 25 倍以上で障害す る重クロム酸カリウムの場合でも覀鉛末を $100 \mathrm{mg}$ に増 すと，200 倍まで影響を示さなかった。

な打無機炭酸塩は有機物中の炭素と同様に及忘するか ら, この種の塩の共存が予測される場合には, あらかじ め塩酸酸性で加熱して追い出してのち蒸発乾固しておこ なえば障害を避けることができる。

イオウおよびイオウ化合物についても同様に影響を検 討したところ，50 倍までは影響を認められなかったが 50 倍以上では障害する.しかし塩化ナトリウム $100 \mathrm{mg}$, 两鉛末 $200 \mathrm{mg}$ 共存のもとでおこなえばイオウは 200 倍

Table II Tested substances which gave positive results

\begin{tabular}{ll}
\hline $\begin{array}{l}\text { Hydrocarbons } \\
\text { and derivs. }\end{array}$ & $\begin{array}{l}\text { Chloroform, iodoform, xylene, naphthalene, } \\
\text { tetraline, tricylchloride }\end{array}$ \\
Alcohols & $\begin{array}{l}\text { Methyl alcohol, ethyl alcohol, tert-butyl } \\
\text { alcohol, allyl alcohol, cyclohexanol, ethylene } \\
\text { glycol, glycerol, cholesterol, ethylene } \\
\text { chlorohydrin }\end{array}$
\end{tabular}

Phenols $\quad \alpha$-Naphthol, resorcinol, thymol, guaiacol

Aldehydes Acetaldehyde, heptyl aldehyde, paraldehyde, vanillin

Ketones Acetone, p-methyl acetophenone, benzophenone, camphor

Carboxylic Acetic acid, oxalic acid, monochloroacetic acids and acid, benzoic acid, acetanilide, ethyl derivs. aminobenzoate

N-Compounds Bromvaleryl urea, dulcin, $\beta$-nitroso- $\alpha$ naphthol, carbazol, glutamic acid

S-Compounds Sulfanilic acid, sulfonal, sulfathiazol, dithizone

Sugars Xylose, glucose

Table III $300 \gamma$ of resorcinol gave positive results in the presence of

\begin{tabular}{|c|c|c|c|c|}
\hline Alkali salts & $\mathrm{NaCl}$ & $1000 \mathrm{mg}$ & $\mathrm{KCl}$ & $500 \mathrm{mg}$ \\
\hline \multirow[t]{2}{*}{ Metals } & $\mathrm{Zn}$ & " & $\mathrm{Fe}$ & 200 \\
\hline & $\mathrm{Mg}$ & 100 & & \\
\hline \multirow[t]{5}{*}{ Metallic oxides } & $\mathrm{PbO}$ & 60 & $\mathrm{HgO}$ & 20 \\
\hline & $\mathrm{Cr}_{2} \mathrm{O}_{3}$ & 20 & $\mathrm{As}_{2} \mathrm{O}_{3}$ & $" \prime$ \\
\hline & $\mathrm{Bi}_{2} \mathrm{O}_{3}$ & $"$ & $\mathrm{Sb}_{2} \mathrm{O}_{3}$ & " \\
\hline & $\mathrm{Al}_{2} \mathrm{O}_{3}$ & " & $\mathrm{K}_{2} \mathrm{Cr}_{2} \mathrm{O}_{2}$ & 5 \\
\hline & $\mathrm{KClO}_{3}$ & 10 & & \\
\hline \multirow[t]{4}{*}{ Sulfur compounds } & s & $\prime \prime$ & $\mathrm{Na}_{2} \mathrm{SO}_{4}$ & 10 \\
\hline & $\mathrm{NaHSO}_{3}$ & " & $\mathrm{Na}_{2} \mathrm{~S}_{2} \mathrm{O}_{3}$ & $" \prime$ \\
\hline & $\mathrm{Na}_{2} \mathrm{SO}_{3}$ & "I & $\mathrm{CuSO}_{4}$ & 20 \\
\hline & $\mathrm{BaSO}_{4}$ & 20 & & \\
\hline
\end{tabular}


まで，亜硫酸水素ナトリウムは 300 倍まで障害しない. また塩化ナトリウム $100 \mathrm{mg}$ ，要鉛末 $500 \mathrm{mg}$ の共存下 ではイオウ污 300 倍共存しても影響はなかったが，500 倍では激しく発火した。.なおイオウの場合は普通の条件 で 100 倍共存してもロダン鉄反応湯性である.

\section{交献}

1) F. Feig1: "Spot Tests in organic Analysis", 73 (1956), (Elsevier Publ. Co., Amsterdam).

2) F. Feig1 : ibid., 74 (1956).

3) F. Feig1 : ibid., 75 (1956).

4) M. Jurecěk, M. Nepraš : Mikrochim. Acta., 1088, 1762 (1956).

5) J. B. Nieder1, J. A. Sozzi : Mikrochim. Acta., 496 500 (1957), C. A., 50, 14446 (1956), C. A., $\mathbf{5 1}, 17590$ (1957).

6)田中善正，山本セツ：日本薬学会九州支部第 4 回 総会発表（1958）。
约

Detection of carbon in organic and inorganic compounds by ignition with sodium amide. Tsutomu Momose, Yo Ueda, and Yoshiko Mukai (Pharmaceutical Institute, Medical Faculty, University of Kyushu)

Sodium amide reacts with various organic and inorganic compounds by heating and gives sodium cyanide. Therefore, detection of carbon is possible by the detection of cyanide ion as Prussian blue. In this reaction, the heating is made under a deninite condition with the addition of sodium chloride and zinc dust in order not to lose sodium cyanide once formed and to give the limit of detection of $40 \sim 75 \gamma$ of carbon. The limit of detection of several representative compounds is shown in Table I; various compounds which showed positive reaction are indicated in Table II; and the effect of coexisting substances is given in Table III.

\title{
クルクミンによる微量ホウ素の比色定量方法の検討 金属ウラン中の微量ホゥ素の比色定量法
}

\author{
吉森 孝良*，武内 次夫**
}

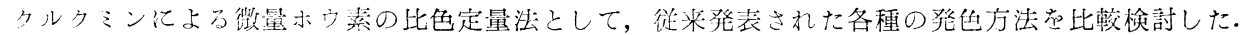

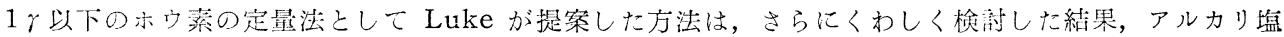

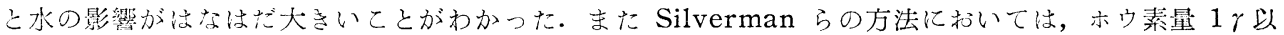

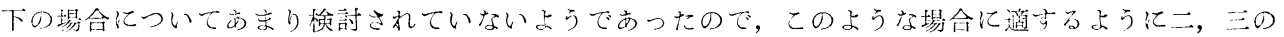
点を改良した。またこの他の方法では結果は思わしくなかった。これらの結棵花金属ウラン中のホウ素

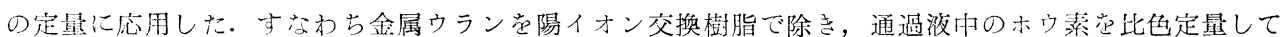
Silverman らの方法の改良法によってほぼ满足な結果を得た。
\end{abstract}

原子灿関係方るいは電子㙨器関係の各種材料におい て, $1 \mathrm{ppm}$ 以下の微量ホウ素の存在が性能に大きく影響 するのて，その定量蛙最近特仙重要視されてきている.

従来使用されたホウ素の定量用試薬のう方，この程度 のホウ素量の圾料に刘しては，クルクミンによる比色法 がもっとも多い上うである1) 7,97. この試薬は感度がよ く，また罣硫酸定使用しないという点が好まれているも の上思和机るが，木ウ酸を発色させる場合の各種の条件， すなわち, 試薬溶液のつくり方, 加光るシュウ酸打よび 塩酸の量と濃度, ならびにとれらの溶液の溶媒, などの 条件がはなはだまちまちであり，結果もかなり異なって

* 岐皁大学工学部 : 波皋県稲葉郡那加町

** 名古屋大学工学部 : 名古屋市千種区不老町
いるようである。著者らは，各種の発你方法を比軟梌討

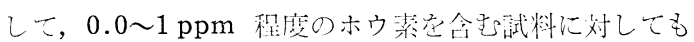

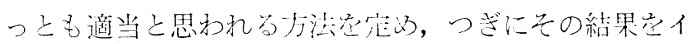
オン交換樹脂分離法と作用して，金属ウラン中のホウ素 の定量に應用して一応の結果在得た。

\section{1 装置ならびに試藻}

\section{$1 \cdot 1$ 装}

発色に使用した白金製蒸発孟虫，直径 $6 \mathrm{~cm}$ ，高さ 3 $\mathrm{cm}$, 容量約 $60 \mathrm{ml}$ のもので, その加温用恒温湯浴注, 全実験を通じて $55 \pm 0.5^{\circ} \mathrm{C}$ に保った。乾燥のたいの空 気の送入は小型ブロワーをもちい，硫酸（90～95\%）岕 よびシリカゲルを通して乾かし，每分 $4.0 \sim 4.2 l$ の速 